\title{
Selected Pacific Northwest Crops as Hosts of Pratylenchus neglectus and $P$. thornei
}

Richard W. Smiley, Professor, Guiping Yan, Research Associate, and Jennifer A. Gourlie, Faculty Research Assistant, Oregon State University, Columbia Basin Agricultural Research Center, P.O. Box 370, Pendleton, OR 97801

\begin{abstract}
Smiley, R. W., Yan, G. P., and Gourlie, J. A. 2014. Selected Pacific Northwest crops as hosts of Pratylenchus neglectus and P. thornei. Plant Dis. 98:1341-1348.

Thirty crop species and cultivars were assayed in the greenhouse for efficiency as hosts of Pratylenchus neglectus and P. thornei. Hosting ability ratings were assigned using the ratio of final versus initial nematode density and also by comparing the final nematode density to that of a susceptible wheat control. Good hosts of both Pratylenchus spp. included oat 'Monida', chickpea 'Myles', and lentil 'Athena' and 'Morton'. Good hosts of $P$. neglectus but not of $P$. thornei included 10 Brassica spp. (5 canola, 2 mustard, and 3 camelina cultivars), chickpea

'Sierra', sudangrass 'Piper', and sorghum/sudangrass hybrid 'Greentreat Plus'. Good hosts of $P$. thornei but not of $P$. neglectus included lentil 'Skyline' and pea 'Granger', 'Journey', and 'Universal'. Poor or minor hosts of both Pratylenchus spp. included chickpea 'Dwelley', pea 'Badminton', safflower 'Gila', 'Girard', and 'KN 144', sunflower '2PD08', flax 'Pembina', eastern gamagrass 'Pete', and switchgrass 'Blackwell'. Results of these assays will provide guidance for improving crop rotation and cultivar selection efficiencies.
\end{abstract}

Root-lesion nematodes (Pratylenchus spp.) are present in 90\% of the fields in low-precipitation regions of the Pacific Northwest (PNW; southern Idaho, eastern Oregon, and eastern Washington) $(13,42,47)$. The most prevalent species in rainfed production systems are P. neglectus (Rensch) Filipjev Schuurmanns \& Stekhoven and $P$. thornei Sher \& Allen. These two species often occur individually, but they also occur as mixtures of species in many fields. $P$. neglectus and $P$. thornei have greater deleterious effects on root growth than on foliar growth, particularly when plants become subjected to drought stress $(3,14,50,51)$. Rainfed wheat (Triticum aestivum L.) yields in low-precipitation regions $(<400 \mathrm{~mm}$ annually) of the PNW are often inversely correlated with the preplant density of Pratylenchus spp. $(40,45,46)$. These species are thought to occur at a density high enough to reduce wheat yields in about $60 \%$ of nonirrigated wheat fields in low-precipitation regions of the PNW, and they have reduced grain yields by as much as $60 \%$ in PNW rainfed wheat without causing obvious foliar symptoms $(38,40,45,46)$. Together, these species are estimated to reduce profitability of wheat production in the PNW by at least $\$ 51$ million annually (37).

$P$. neglectus and $P$. thornei invade roots of many monocot and dicot crops $(4,43,51,54)$. Resistant nonadapted wheat cultivars have been identified, but all commercial cultivars of PNW wheat tested thus far were susceptible and heterogeneous for tolerance (3338,49). Barley (Hordeum vulgare L.) cultivars are generally more resistant than commercial wheat cultivars (34-37). While wheat is by far the dominant economically viable rainfed crop in the lowprecipitation zone of the PNW (32), field studies with potential rotation crops have provided insights of root-lesion nematode dynamics in dryland cropping systems (41). For instance, Pratylenchus spp. densities were typically suppressed when barley was produced, as compared to canola (Brassica campestris L. and B. napus L.) or wheat $(40,41,46)$. In low-precipitation regions, growers often report higher wheat yields when wheat follows barley compared to wheat planted after wheat, canola, or chickpea (Cicer

Corresponding author: R. Smiley, E-mail: richard.smiley@ oregonstate.edu

Accepted for publication 4 April 2014.

http://dx.doi.org/10.1094/PDIS-12-13-1296-RE

(C) 2014 The American Phytopathological Society arietinum L.). These observations are important in view of increasing interest in soil-conserving farming systems that include annual spring crops, including no-till production of potential food legume crops, and cruciferous food and biofuel crops. However, very few PNW crop species and cultivars have been examined in crop rotation studies, and essentially nothing is known about the hosting ability (comparative rates of nematode multiplication in controlled environments) of specific North American cultivars of noncereals such as canola, mustard (Brassica juncea (L.) Czern. and Sinapsis alba L.), safflower (Carthamus tinctorius L.), field pea (Pisum sativum L.), and lentil (Lens culinaris Medik.). Research overseas has revealed that some crops promoted as rotational options for wheat, to "break the disease cycle", are very efficient in allowing multiplication of $P$. neglectus and/or P. thornei, and therefore capable of increasing the level of risk to a subsequent intolerant cultivar of a crop such as wheat $(18,48,51,54)$. Rotation crops of interest to farmers in rainfed low-precipitation regions of the PNW include canola and chickpea, each of which is a particularly good host for one or both Pratylenchus spp. in other countries $(3,8,47)$. High densities of $P$. neglectus have also been detected following production of cruciferous crops (Brassicaceae family) in the PNW $(40,42,44,46)$, but documentation of specific hosting abilities of these crops is lacking. The traditional rotation of food legumes with cereals is not recommended in fields infested by $P$. thornei in the Mediterranean Basin because this nematode multiplied efficiently on lentil, pea, and other leguminous crops in those regions $(12,25)$. However, in Australia, most cultivars of lentil and pea are considered resistant or moderately resistant to both $P$. neglectus and $P$. thornei $(18,48,54)$. Both of these nematodes have been associated with reduced yields of a few lentil and pea cultivars in the PNW (31).

Knowledge of hosting abilities by noncereal crops in the PNW will become increasingly important as production increases for biofuel and biomass-producing crops such as canola, mustard, camelina (Camelina sativa (L.) Crantz), switchgrass (Panicum virgatum L.), and eastern gamagrass (Tripsacum dactyloides (L.) L.). Webb (55) reported that $P$. neglectus and P. thornei were each capable of invading and multiplying in four cultivars of oilseed rape (B. napus). Field studies by Australian scientists showed that densities of $P$. neglectus but not of $P$. thornei were likely to be increased by canola $(18,27,54)$. Even some biofumigant greenmanure crops such as mustard and sorghum (Sorghum bicolor (L.) Moench) are capable of increasing the density of Pratylenchus spp. 
in roots and soil before the green foliage is macerated and incorporated into the soil, whereupon disrupted plant cells release toxic products that expedite a decline in the number of nematodes remaining in soil $(9,20,28,29)$. If those same crops are grown to maturity for extraction of oil from seed, as almost always occurs in rainfed low-precipitation areas of the PNW, the Pratylenchus spp. density may remain elevated $(40,41)$. Likewise, sorghum was reported as a host of $P$. thornei in South Australia (23) but not of $P$. neglectus in Kansas (7). In contrast, Thompson et al. (51) considered sorghum to be resistant to $P$. thornei but not to $P$. neglectus in Queensland, Australia. Cultivars of sudangrass and a sudangrass $\times$ sorghum hybrid (Sorghum $\times$ drummondii Nees ex Steud.) Millsp. $\&$ Chase) have been found to be good hosts of P. penetrans $(11,19)$ and to also serve as a Pratylenchus-suppressing biofumigant when green vegetation of those hosts were incorporated into soil of an irrigated field in the PNW (11).

The objective of this research was to characterize selected crop species and cultivars of potential importance to PNW wheat producers for their ability to serve as hosts of $P$. neglectus and P. thornei.

\section{Materials and Methods}

Thirty crop species and cultivars were assayed as two separate plant groups (monocots and dicots) and separately for the two nematode species: $P$. neglectus and $P$. thornei. The four assays were performed twice during successive years under semicontrolled conditions in a greenhouse at Oregon State University's Columbia Basin Agricultural Research Center, near Pendleton, OR.

Table 1. Plant entries assayed for hosting efficiencies of Pratylenchus neglectus and P. thornei

\begin{tabular}{|c|c|c|c|}
\hline $\begin{array}{l}\text { Plant } \\
\text { family }\end{array}$ & Genus and species & Common name & Cultivar \\
\hline Asteracae & Carthamus tinctorius & Spring safflower & Gila \\
\hline Asteracae & Carthamus tinctorius & Spring safflower & Girard \\
\hline Asteracae & Carthamus tinctorius & Winter safflower & KN 144 \\
\hline Asteraceae & Helianthus аппииs & Sunflower & 2PD08 \\
\hline Brassicaceae & Brassica campestris & Canola (spring rape) & Goldrush \\
\hline Brassicaceae & Brassica campestris & Canola (spring rape) & Hyola 401 \\
\hline Brassicaceae & Brassica napus & Canola (winter rape) & Amanda \\
\hline Brassicaceae & Brassica napus & Canola (winter rape) & Dwarf Essex \\
\hline Brassicaceae & Brassica napus & Canola (winter rape) & Salut \\
\hline Brassicaceae & Brassica juncea & Brown mustard & Pacific Gold \\
\hline Brassicaceae & Sinapsis alba & Yellow mustard & IdaGold \\
\hline Brassicaceae & Camelina sativa & Camelina & Blaine Creek \\
\hline Brassicaceae & Camelina sativa & Camelina & Calena \\
\hline Brassicaceae & Camelina sativa & Camelina & Yellowstone \\
\hline Fabaceae & Cicer arietinum & Chickpea & Dwelley \\
\hline Fabaceae & Cicer arietinum & Chickpea & Myles \\
\hline Fabaceae & Cicer arietinum & Chickpea & Sierra \\
\hline Fabaceae & Pisum sativum & Green field pea & Journey \\
\hline Fabaceae & Pisum sativum & Yellow field pea & Badminton \\
\hline Fabaceae & Pisum sativum & Yellow field pea & Universal \\
\hline Fabaceae & Pisum sativum & $\begin{array}{l}\text { Austrian winter field } \\
\text { pea }\end{array}$ & Granger \\
\hline Fabaceae & Lens culinaris & Lentil & Athena \\
\hline Fabaceae & Lens culinaris & Winter lentil & Morton \\
\hline Fabaceae & Lens culinaris & Lentil & Skyline \\
\hline Linaceae & Linum usitatissimит & Flax & Pembina \\
\hline Poaceae & Avena sativa & Oat & Monida \\
\hline Poaceae & Panicum virgatum & Switchgrass & Blackwell \\
\hline Poaceae & Sorghum bicolor & Sudangrass & Piper \\
\hline Poaceae & $\begin{array}{l}\text { Sorghum } \times \\
\text { drummondii }\end{array}$ & $\begin{array}{l}\text { Sudangrass/sorghum } \\
\text { hybrid }\end{array}$ & $\begin{array}{l}\text { Greentreat } \\
\text { Plus }\end{array}$ \\
\hline Poaceae & $\begin{array}{l}\text { Tripsacum } \\
\text { dactyloides }\end{array}$ & Eastern gamagrass & Pete \\
\hline Poaceae & Triticum aestivum & $\begin{array}{l}\text { Resistant landrace } \\
\text { wheat }^{\mathrm{y}}\end{array}$ & AUS28451 \\
\hline Poaceae & Triticum aestivum & Susceptible wheat ${ }^{z}$ & Louise \\
\hline Poaceae & Triticum aestivum & Susceptible wheat ${ }^{\mathrm{z}}$ & Otis \\
\hline
\end{tabular}

${ }^{y}$ Landrace wheat control cultivar that exhibited moderate resistance to $P$. neglectus and $P$. thornei in previous experiments.

${ }^{\mathrm{z}}$ Pacific Northwest wheat control cultivars that exhibited susceptible reactions to $P$. neglectus and $P$. thornei in previous experiments.
Test plants and controls. Plant entries (Table 1) included 30 cultivars of canola, camelina, chickpea, flax (Linum usitatissimum L.), lentil, mustard, oat (Avena sativa L.), pea, safflower, sudangrass, sudangrass/sorghum hybrid, sunflower (Helianthus annuus L.), eastern gamagrass, and switchgrass. Entries were nominated and/or supplied by local agronomists having interests in these crops and cultivars.

Controls included inoculated unplanted soil, noninoculated unplanted soil, two Pratylenchus-susceptible wheat cultivars ('Louise' and 'Otis'; 35,49), and a moderately resistant landrace wheat cultivar 'AUS28451' (33-35,39,49). The resistant wheat was compared to the susceptible wheat controls to identify and interpret potential instances where the susceptible wheat may have a potentially low rate of multiplication due to anomalies associated with experimental conditions unfavorable to Pratylenchus multiplication, or circumstances of an unexpectedly low virulence level of the nematode inoculum. The susceptible and resistant wheat controls were used to make direct comparisons with unknown plant entries and the unplanted inoculated soil control. The inoculated unplanted soil control was included to allow for evaluation of inoculum survival in the absence of a host plant, and for comparisons of final nematode densities in planted versus unplanted soil. The noninoculated unplanted soil control served to determine whether nematodes were transferred from one assay pot to another during the watering process.

Assay procedure. Assays were conducted in a manner similar to that described for previous assays of wheat and barley $(33-35,49)$. An Adkins fine sandy loam was passed through a 4-mm screen, lightly moistened, incubated for several days, and treated in an oven at $90^{\circ} \mathrm{C}$ for 2 days to kill active nematodes. Soil was then stored in closed bins to allow for microbial and chemical stabilization.

Monocotyledonous plant species were assayed in cones measuring 3.8- $\mathrm{cm}$ top diameter $\times 20 \mathrm{~cm}$ tall (Ray Leach S10 Super Conetainers; Stuewe and Sons, Inc., Corvallis, OR). The wheat and unplanted soil controls were also assayed in the S10 cones. Individual cones were filled with $160 \mathrm{~g}$ of soil after cotton balls were placed at the bottom of each cone to retain soil that would otherwise escape through the holes at the bottom. Cones were held vertical in RL98 support trays which in turn were placed within FlowTSM flow trays (Stuewe and Sons) to facilitate capillary watering through subirrigation.

Dicotyledonous plant entries were assayed in the same manner except that they were planted into $600 \mathrm{~g}$ of soil in larger cones measuring 6.4-cm top diameter $\times 25.4 \mathrm{~cm}$ tall (D40 Deepots; Stuewe and Sons). These cones were supported by D20T Support Trays capable of holding 20 Deepots. For these assays, the unplanted soil and wheat controls were also planted into the D40 Deepots.

Assays were performed as four separate blocks, each with its own controls: monocots inoculated with either $P$. neglectus or $P$. thornei, or dicots inoculated with either P. neglectus or P. thornei. Initiation of each assay was offset by a 1- to 2 -week interval to assure availability of nematode inoculum and labor for each phase of each assay. For individual assays, one seed of each plant species was placed into each of eight pots (replicates). Each plant species and cultivar was compared to the controls that were also replicated and arranged with other entries as randomized complete blocks within each of the four assays. Multiple replicates were placed into individual flow trays. Assays involving P. neglectus or P. thornei were placed into different flow trays. After planting, the soil was subirrigated to moisten the soil by capillary action. This was accomplished by placing water in the flow tray to a level just covering the holes at the bottoms of all cones. Excess water was siphoned from the trays 1 day after watering was initiated. This process was repeated each time the soil surface in most cones appeared to be dry, for which the timing varied as plants became established and matured.

When a seedling failed to emerge, the cone was replanted and marked for an appropriate set-back of timings for inoculation and 
harvest. Cones of soil were removed from the assay if seedlings failed to become established after three plantings.

Plant nutrients were supplied 3 weeks after planting by inserting slow-release fertilizer cylinders $(5 \mathrm{~mm}$ diameter $\times 50 \mathrm{~mm}$ long; $13 \% \mathrm{~N}, 4 \% \mathrm{P}_{2} \mathrm{O}_{5}, 5 \% \mathrm{~K}_{2} \mathrm{O}$; Jobe's Fertilizer Spikes, Easy Gardener, Inc., Waco, TX) into each cone. One cylinder was placed into smaller cones used to assay monocots and two cylinders were placed into cones used to assay dicots. Additional fertilizer was supplied with the irrigation water during the latter stages of incubation, using Miracle-Gro All-Purpose Plant Food $(15 \%$ N, 30\% $\mathrm{P}_{2} \mathrm{O}_{5}, 15 \% \mathrm{~K}_{2} \mathrm{O}$, plus micronutrients; Scotts Miracle-Gro Products, Marysville, $\mathrm{OH}$ ). Aphids were controlled by foliar applications of esfenvalerate (Bug-B-Gon Multi-purpose Insect Killer, Ortho, Inc., Columbus, $\mathrm{OH}$ ), and powdery mildew was controlled by foliar applications of triadimefon (Bayleton, Mobay Chemical Co., Kansas City, MO).

The four assays were performed during 2011 and were repeated during 2012, using the same seed lots and nematode parent cultures each year. Assays were conducted in a greenhouse maintained at about $22^{\circ} \mathrm{C}$, and with daylight supplemented by a 12-h period using 1,000-watt high-pressure sodium horticultural lamps. During the second year, cones were hand watered from the top to avoid the potential for soil saturation that may have occurred with the bottom watering method used during 2011. During 2012, each pot was watered to a gravimetric content of about $0.25 \mathrm{~g} / \mathrm{g}$ as needed, and fertilizer was applied using the same sources and timing, except that the Miracle-Gro was applied with irrigation water applied to the soil surface.

Inoculum, inoculation, and extraction. $P$. neglectus and $P$. thorne $i$ were isolated from infested fields. Inoculum of $P$. neglectus was a composite of five individual cultures derived from populations at four Oregon locations (Adams: 45.7205, -118.6256; Imbler: 45.3750, -117.9455; Moro: 45.4852, -120.7126; and Union: $45.2955,-117.9494$ ) and one Washington location (Lind: 47.0010, -118.5582). A single isolate of $P$. thornei was derived from a field near Adams, OR (45.7181, -118.6283). Single surface-sterilized adult females were placed onto sterilized carrot disks to establish pure cultures of each isolate (22). Cultures were incubated at $22^{\circ} \mathrm{C}$ for at least 3 months, and the species in each culture was identified using morphological and molecular methods $(16,57)$. Inoculum of each species was increased by transferring a small number of individuals from stock laboratory carrot cultures onto additional surface-sterilized carrot disks maintained individually in petri dishes under aseptic conditions in a laboratory incubator. Mature cultures were evaluated to assure nematode purity and vitality. Inocula for use in greenhouse assays were extracted by cutting the carrot disks into thin slices and floating the carrot pieces in distilled water in a petri dish. Nematodes were recovered using a $20-\mu \mathrm{m}$ sieve and were stored for short periods at $8^{\circ} \mathrm{C}$ before use.

Soil was inoculated approximately 2 weeks after planting, soon after seedling emergence. An aqueous suspension of nematodes was placed into small diameter holes made in the surface $2 \mathrm{~cm}$ of soil on either side of the seedling. Inoculum during 2011was applied as $2,700 \mathrm{P}$. neglectus or $2,900 \mathrm{P}$. thornei $/ \mathrm{kg}$ of soil for assays of monocots, and 2,014 P. neglectus or 2,128 P. thornei $/ \mathrm{kg}$ of soil for assays of dicots. During 2012, inoculum was applied as 2,500 P. neglectus or 2,594 P. thornei/kg of soil for assays of monocots, and 2,317 P. neglectus or 2,017 P. thornei $/ \mathrm{kg}$ of soil for assays of dicots.

Experiments were terminated 16 and 12 weeks after inoculation during 2011 and 2012, respectively. Shoots were removed from plants and the roots and soil from each cone were stored in a cold room until nematodes were extracted and counted. Soil and roots were finely chopped and nematodes were extracted from soil and roots over a 48-h period using the Whitehead tray method (56). Nematodes were collected by wet sieving (U.S.A. Standard Testing Sieve No. 635; $20 \mu \mathrm{m}$ openings) and were quantified using a counting slide viewed under a dissecting microscope.

Reproductive factor and hosting ability rating. Reproductive factors $(R f ; 24)$ were calculated for each treatment by dividing the final nematode density $(P f)$ by the initial nematode inoculum den- sity $(P i)$. Five hosting ability groups were designated to simplify interpretation of the data: nonhosts $(R f<0.1 ; 21)$, poor hosts $(R f=$ 0.1 to $0.9 ; 21)$, minor hosts $(R f=1.0$ to 4.9$)$, good hosts $(R f=5.0$ to 9.9$)$, and very good hosts $(R f \geq 10 ; 10)$.

Statistical analysis. Nematode counts $(P f$, nematodes $/ \mathrm{kg}$ of soil $)$ were normalized using the $\ln (x+1)$ transformation (30). Data for the four assays ( 2 plant family groups $\times 2$ Pratylenchus spp.) were analyzed separately each year using ANOVA. Main treatments were entry and replicates were blocks. ANOVA was performed using CoStat Statistical Software (CoStat version 6.400; CoHort Software, Minneapolis, MN). When treatment means were significant at $P<0.05$, means were separated using the Least Significant Difference (LSD) test. The LSD test was applied because numbers of replicates with established plants were less than eight for some plant entries, particularly during 2011. The $R f$ values that had been calculated using nontransformed data were also analyzed separately by experiment and year. Means of $R f$ values and standard errors of the means were calculated and when means were significant at $P<0.05$, they were separated using the LSD test.

\section{Results}

Very few Pratylenchus spp. (0 to 50 nematodes $/ \mathrm{kg}$ of soil; mean $=2.1$ ) were detected in soil that had not been inoculated (data not presented), indicating that little or no transfer of nematodes occurred in the irrigation water. Likewise, only a few containers revealed the presence of non-plant-parasitic nematode species at the end of each of the eight assays, indicating that few nematodes survived the heat treatment initially applied to soil.

Densities of Pratylenchus spp. declined dramatically in the absence of a host plant during the 16- and 12-week assay periods during 2011 and 2012, respectively. During 2011, the nematode density was 98 to $99 \%$ lower at the end than at the beginning of all four assays (Tables 2 and 3), indicating that assay conditions during 2011 were unfavorable to these nematodes in the absence of a host. During 2012, there were 80 to $84 \%$ fewer Pratylenchus spp. in unplanted, inoculated soils than were inoculated into soils for monocots (Table 2) and 61 to $69 \%$ fewer Pratylenchus spp. than were inoculated into soils for dicots (Table 4), indicating a more favorable environment for nematode survival during 2012 than 2011 , as well as an incubation period that was $25 \%$ shorter, during which time nematode mortality may have occurred in the absence of a host.

Seedling emergence and plant establishment were more complete for all four assays during 2012 compared to 2011. In the assay of five monocots other than wheat against $P$. neglectus, plants established successfully and were harvested for 35 of 40 possible pots $(88 \%)$ during 2012 (Table 2) but for only 24 of 40 pots $(60 \%)$ during 2011 (Table 2). Successful cultures for monocots screened against $P$. thornei were 88 and $70 \%$ during 2012 and 2011, respectively (Table 2). Growth and development of nearly all monocot and dicot entries were more normal during 2012 compared to 2011. While numbers of successful cultures during 2011 were limited for some plant entries, the data for successful cultures during 2011 served as important comparisons with results from the more robust experiment conducted during 2012.

Fewer Pratylenchus spp. were extracted from resistant than from susceptible wheat in all eight assays. Differences were significant $(P<0.05)$ in all four monocot assays when analyses were based upon log-transformed data and in the three monocot trials where differences of $R f$ values could be separated by the LSD test (Table 2). Numerical $P f$ values for resistant and susceptible wheat differed greatly in the dicot experiments during 2011, but the differences were generally not significant (Table 3 ). The repetition of the dicot experiments during 2012 produced significant differences between resistant and susceptible wheat controls using comparisons by both methods: back-transformed means and $R f$ values. The low $R f$ values for susceptible wheat cultivars in assays of $P$. thornei during 2011 indicated that those trials were of questionable value for interpreting results of assays of these nematodes against the crop plants having unknown hosting abilities. In contrast, all four assays 
of susceptible controls during 2012 resulted in multiplication rates greater than 10, which provided excellent opportunities to compare susceptible wheat with other plant entries.

Assignments of hosting ability categories were therefore based on assays during 2012 because there was a poor correlation of multiplication rates across these years within assays. Also, during 2012 compared to 2011, there was a greater rate of survival of inoculum in the absence of host plants, a much higher nematode multiplication rate on susceptible plants, a greater rate of plant survival, improved plant vigor, and greater uniformity of data among replicates.

For the five monocot entries in the experiment with $P$. neglectus during 2012, four had significantly $(P<0.05)$ lower $R f$ values than the susceptible wheat Louise, and all five entries had significantly lower $R f$ values than susceptible wheat Otis (Table 2). All five entries had lower $R f$ values than the susceptible wheat controls in the experiment with $P$. thornei. When comparisons were based upon back-transformed means, three entries (sudangrass 'Piper', sorghum/sudangrass 'Greentreat Plus', and oats 'Monida') did not differ from the susceptible wheat controls in the experiment with $P$. neglectus, whereas only oats Monida failed to differ in the experiment with $P$. thornei. Of the monocots tested, only the two biomass entries, eastern gamagrass 'Pete' and switchgrass 'Blackwell', were rated as poor hosts of both nematode species.

For dicots tested against $P$. neglectus during 2012, none of the 10 brassica species differed from both of the susceptible wheat controls when evaluated by both methods of comparing means (Table 4). Brown mustard 'Pacific Gold' had a back-transformed mean significantly less than the wheat controls, but the difference was not significant when evaluated using the $R f$ values. All brassica species were categorized as good to very good hosts of $P$. neglectus. Chickpea and lentil cultivars were variable in response to $P$. neglectus. Chickpea 'Dwelley' supported significantly less multi- plication, but 'Myles' and 'Sierra' did not differ from the controls and were rated as good hosts of P. neglectus. Lentil 'Skyline' but not 'Athena' and 'Morton' also had significantly lower multiplication rates than the wheat controls. Athena and Morton were considered good hosts of $P$. neglectus. Compared to the susceptible wheat controls using both methods of means comparisons, all nine pea, safflower, sunflower, and flax cultivars had significantly lower rates of multiplication for $P$. neglectus, and none were considered to be a good host of this nematode species.

For dicots tested against $P$. thornei during 2012, all 10 brassica, three chickpea, and five safflower, sunflower, and flax entries had significantly lower back-transformed means and also significantly lower $R f$ values compared to the susceptible wheat controls. All except one of these 18 entries were considered to be poor or minor hosts of $P$. thornei. The exception was for chickpea Myles, which was rated as a very good host of $P$. thornei based upon the scale used for grouping the $R f$ values into phenotypic response categories. Six of seven cultivars of pea and lentil were considered good or very good hosts of $P$. thornei. The exception was yellow pea 'Badminton'.

Overall, only four crops were classified as a good or very good host to both species of Pratylenchus (Tables 3 and 4): oats Monida, chickpea Myles, and lentil Athena and Morton. Thirteen entries were good hosts of $P$. neglectus but not of $P$. thornei, including all 10 brassica crops. In contrast, good hosts of $P$. thornei but not of $P$. neglectus included four entries among the pea and lentil cultivars. Nine entries were poor to minor hosts to both Pratylenchus spp., two pea and chickpea cultivars, all five nonbrassica oilseed crops, and the two biomass-producing monocots.

\section{Discussion}

Multiplication rates of $P$. neglectus and $P$. thornei were evaluated in the greenhouse for 30 crop species and cultivars including 10

Table 2. Multiplication rates and hosting abilities of Pratylenchus neglectus and P. thornei for monocotyledonous cultivars and species during 2011 and 2012

\begin{tabular}{|c|c|c|c|c|c|c|c|c|c|}
\hline \multirow{2}{*}{$\begin{array}{l}\text { Pratylenchus spp. and assay } \\
\text { plant or soil }\end{array}$} & \multirow[b]{2}{*}{ Cultivar } & \multicolumn{4}{|c|}{2011} & \multicolumn{4}{|c|}{2012} \\
\hline & & BTM $^{w}$ & $R f \pm \mathrm{SE}^{\mathrm{x}}$ & $\mathbf{N}^{\mathrm{y}}$ & $\mathbf{H}^{\mathbf{z}}$ & BTM & $R f \pm \mathrm{SE}$ & $\mathbf{n}$ & $\mathbf{H}$ \\
\hline \multicolumn{10}{|l|}{ P. neglectus } \\
\hline Unplanted soil, inoculated & $\ldots$ & $24 \mathrm{c}$ & $0.1 \pm 0.1 \mathrm{~b}$ & 8 & $\ldots$ & $388 \mathrm{e}$ & $0.3 \pm 0.1 \mathrm{~d}$ & 8 & $\ldots$ \\
\hline Susceptible wheat & Louise & $17,580 \mathrm{a}$ & $9.2 \pm 1.4 \mathrm{a}$ & 8 & G & $28,287 \mathrm{a}$ & $13.6 \pm 3.2 \mathrm{ab}$ & 8 & VG \\
\hline Susceptible wheat & Otis & 23,599 a & $10.6 \pm 2.3 \mathrm{a}$ & 7 & VG & $34,039 \mathrm{a}$ & $18.8 \pm 3.6 \mathrm{a}$ & 8 & VG \\
\hline Resistant wheat & AUS28451 & $146 \mathrm{bc}$ & $0.8 \pm 0.7 \mathrm{~b}$ & 8 & $\mathrm{P}$ & $13,315 \mathrm{~b}$ & $5.8 \pm 0.8 \mathrm{c}$ & 8 & $\mathrm{G}$ \\
\hline Eastern gamagrass & Pete & $8 \mathrm{c}$ & $0.1 \pm 0.1 \mathrm{~b}$ & 3 & $\mathrm{P}$ & $1,639 \mathrm{c}-\mathrm{e}$ & $0.9 \pm 0.4 \mathrm{~cd}$ & 3 & $\mathrm{P}$ \\
\hline Switchgrass & Blackwell & $9 \mathrm{c}$ & $0.0 \pm 0.0 \mathrm{~b}$ & 2 & $\mathrm{~N}$ & $30 \mathrm{f}$ & $0.1 \pm 0.0 \mathrm{~d}$ & 8 & $\mathrm{P}$ \\
\hline Sudangrass & Piper & $2,004 \mathrm{ab}$ & $2.0 \pm 1.1 \mathrm{~b}$ & 7 & M & $23,710 \mathrm{a}$ & $12.6 \pm 1.7 \mathrm{~b}$ & 8 & VG \\
\hline Oats & Monida & 8,714 a & $9.6 \pm 3.3 \mathrm{a}$ & 6 & $\mathrm{G}$ & $17,525 \mathrm{ab}$ & $7.2 \pm 0.8 \mathrm{c}$ & 8 & $\mathrm{G}$ \\
\hline Sorghum/sudangrass cross & Greentreat Plus & $164 \mathrm{bc}$ & $0.3 \pm 0.2 b$ & 6 & $\mathrm{P}$ & $14,395 \mathrm{ab}$ & $7.0 \pm 1.0 \mathrm{c}$ & 8 & G \\
\hline$P>F$ & & $<0.0001$ & 0.0010 & & & $<0.0001$ & $<0.0001$ & & \\
\hline $\mathrm{CV}(\%)$ & & 39.4 & 112.0 & & & 17.1 & 62.9 & & \\
\hline \multicolumn{10}{|l|}{ P. thornei } \\
\hline Unplanted soil, inoculated & $\ldots$ & $11 \mathrm{~b}$ & $0.1 \pm 0.1$ & 8 & $\ldots$ & $514 \mathrm{de}$ & $0.4 \pm 0.1 \mathrm{~d}$ & 8 & \\
\hline Susceptible wheat & Louise & $3,752 \mathrm{a}$ & $3.9 \pm 1.4$ & 8 & $\mathrm{M}$ & $47,996 \mathrm{a}$ & $21.9 \pm 2.4 \mathrm{a}$ & 8 & VG \\
\hline Susceptible wheat & Otis & 6,944 a & $7.1 \pm 1.8$ & 7 & $\mathrm{G}$ & 54,627 a & $21.3 \pm 2.1 \mathrm{a}$ & 8 & VG \\
\hline Resistant wheat & AUS28451 & $292 \mathrm{~b}$ & $0.9 \pm 0.7$ & 8 & $\mathrm{P}$ & $16,930 \mathrm{~b}$ & $6.9 \pm 0.8 \mathrm{c}$ & 8 & $\mathrm{G}$ \\
\hline Eastern gamagrass & Pete & $6 \mathrm{~b}$ & $0.0 \pm 0.0$ & 6 & $\mathrm{~N}$ & $172 \mathrm{e}$ & $0.1 \pm 0.0 \mathrm{~d}$ & 3 & $\mathrm{P}$ \\
\hline Switchgrass & Blackwell & $0 \mathrm{~b}$ & 0.0 & 1 & $\mathrm{~N}$ & $1,021 \mathrm{~cd}$ & $0.5 \pm 0.2 \mathrm{~d}$ & 8 & $\mathrm{P}$ \\
\hline Sudangrass & Piper & $17 \mathrm{~b}$ & $0.1 \pm 0.0$ & 8 & $\mathrm{P}$ & $5,279 \mathrm{~b}$ & $2.3 \pm 0.5 \mathrm{~d}$ & 8 & M \\
\hline Oats & Monida & $2,240 \mathrm{a}$ & $2.3 \pm 1.6$ & 5 & M & $26,030 \mathrm{a}$ & $12.4 \pm 3.3 \mathrm{~b}$ & 8 & VG \\
\hline Sorghum/sudangrass cross & Greentreat Plus & $22 \mathrm{~b}$ & $0.0 \pm 0.0$ & 8 & $\mathrm{~N}$ & $2,784 \mathrm{bc}$ & $1.2 \pm 0.2 \mathrm{~d}$ & 8 & $\mathrm{M}$ \\
\hline$P>F$ & & $<0.0001$ & 0.0766 & & & $<0.0001$ & $<0.0001$ & & \\
\hline $\mathrm{CV}(\%)$ & & 58.8 & 257.5 & & & 14.2 & 74.1 & & \\
\hline
\end{tabular}

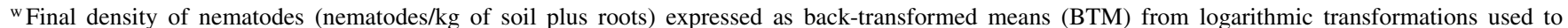
normalize data for ANOVA. Within a column, means followed by the same letter for each of the comparisons in eight assays did not differ significantly at $P$ $<0.05$ according to ANOVA using Least Significant Difference to separate means. Assays were over 16- and 12-week incubation periods during 2011 and 2012 , respectively.

${ }^{\mathrm{x}}$ Reproductive factor $(R f)$ and standard error of the mean (SE) calculated as the final nematode density (Pf, nematodes/kg of soil) divided by the density of Pratylenchus initially added into soil ( $P i$, nematodes/kg of soil); Pi rates were 2,700 and 2,500 P. neglectus/kg of soil during 2011 and 2012 , respectively, and 2,900 and 2,594 P. thornei/kg of soil during 2011 and 2012, respectively.

${ }^{\mathrm{y}}$ Number of observations included in the analysis; $\mathrm{n}<8 / \mathrm{year}$ indicates a failure of seedling establishment.

${ }^{\mathrm{z}}$ Hosting ability ratings: $\mathrm{N}=$ nonhost $(R f<0.1), \mathrm{P}=$ poor host $(R f=0.1$ to 0.9$), \mathrm{M}=$ minor host $(R f=1.0$ to 4.9$), \mathrm{G}=$ good host $(R f=5.0$ to 9.9$), \mathrm{VG}=$ very good host $(R f \geq 10.0)$. 
cultivars of cruciferous oilseeds, three safflower cultivars, three chickpea cultivars, four cultivars of two species of pea, three lentil cultivars, two biomass-producing crops, and one cultivar each of flax, oat, sunflower, sudangrass, and a sorghum/sudangrass hybrid. Assays were repeated over 2 years, and hosting abilities were evaluated using two procedures, one based on relative reproductive factor ratios and the other based on final nematode densities compared to two susceptible wheat cultivars. Both systems provided useful insights into the hosting abilities of these Pratylenchus spp., particularly during the second assay year when plant growth and incubation conditions were more hospitable for the nematodes and for plant growth, as compared to the first assay year.

Oat Monida was a good host of both $P$. neglectus and P. thornei. Variable hosting abilities among oat cultivars have been reported for $P$. neglectus $(48,53)$ and $P$. thornei (17). Thompson et al. (51) listed oats as being of intermediate susceptibility to these species, and Vanstone et al. (54) listed oats as being resistant to P. thornei and susceptible to $P$. neglectus. Our testing of a single oat cultivar indicated that Monida is capable of increasing the density of both $P$. neglectus and $P$. thornei in PNW fields. Forge et al. (11) also demonstrated that several other oat cultivars were good hosts of $P$. penetrans in the PNW.

Two biomass-producing plant species of potential interest to PNW farmers were poor hosts of both Pratylenchus spp. The multiplication factors for switchgrass Blackwell and eastern gamagrass Pete were always less than one, indicating that both crops could be expected to reduce densities of these nematodes in PNW fields. However, these crops are more likely to be produced in irrigated fields where they may encounter $P$. penetrans as well as $P$. neglec- tus and P. thornei (11). We are not aware of previous reports of hosting abilities of these crops for any species of Pratylenchus.

Sudangrass Piper and the sorghum/sudangrass hybrid Greentreat Plus were more efficient hosts of $P$. neglectus than of $P$. thornei. Likewise, sorghum was shown to be a host of $P$. thornei in South Australia (23) but not of P. neglectus in Kansas (7). In contrast, Thompson et al. (51) considered sorghum to be resistant to P. thornei but not to P. neglectus in Queensland, Australia. MacGuidwin and Layne (19) reported that cultivars of sudangrass (including Piper) and sorghum/sudangrass hybrids managed as green manure crops failed to suppress the density of $P$. penetrans in soil, which contrasts with reports that these crops served as Pratylenchussuppressing biofumigants when green vegetation was incorporated into an irrigated field in the PNW (11). Mojtahedi et al. (21) reported that some cultivars of sudangrass and sorghum/sudangrass were suitable hosts of Meloidogyne chitwoodi while other cultivars were poor or nonhosts. Moreover, for one of the poor to nonhost cultivars, these authors determined that macerated root tissue used as a green manure failed to inhibit reproduction of $M$. chitwoodi, whereas macerated stem and leaf tissues were efficient inhibitors of this nematode. In rainfed agricultural systems, it appears that these crops grown for seed production could have variable effects on the density of Pratylenchus spp. in soil depending upon the cultivar $\times$ pathogen combination.

All 10 cruciferous oilseed crops within the Brassicaceae family were good to very good hosts of $P$. neglectus and poor to minor hosts of $P$. thornei. This relationship included all cultivars of canola, camelina, yellow mustard, and brown mustard. Canola 'Amanda' was the most efficient host of P. neglectus encountered

Table 3. Multiplication rates and hosting abilities of Pratylenchus spp. for cultivars and species within dicotyledonous plant families during 2011

\begin{tabular}{|c|c|c|c|c|c|c|c|c|c|}
\hline \multirow[b]{2}{*}{ Common name } & \multirow[b]{2}{*}{ Cultivar } & \multicolumn{4}{|c|}{ P. neglectus } & \multicolumn{4}{|c|}{ P. thornei } \\
\hline & & BTM $^{w}$ & $R f \pm \mathrm{SE}^{\mathrm{x}}$ & $\mathbf{N}^{\mathrm{y}}$ & $\mathbf{H}^{\mathbf{z}}$ & BTM & $R f \pm \mathrm{SE}$ & $\mathbf{n}$ & $\mathbf{H}$ \\
\hline Unplanted soil, inoculated & & $43 \mathrm{~b}$ & $0.1 \pm 0.0$ & 8 & $\ldots$ & $10 \mathrm{bc}$ & $0.0 \pm 0.0 \mathrm{~d}$ & 8 & $\ldots$ \\
\hline Susceptible wheat & Louise & $8,829 a b$ & $7.4 \pm 2.4$ & 5 & G & $1,622 \mathrm{a}$ & $0.6 \pm 0.2 \mathrm{~b}-\mathrm{d}$ & 8 & $\mathrm{P}$ \\
\hline Susceptible wheat & Otis & $4,485 a b$ & $4.7 \pm 1.9$ & 6 & $\mathrm{M}$ & 3,314 a & $1.6 \pm 0.6 \mathrm{a}$ & 6 & M \\
\hline Resistant wheat & AUS28451 & $31 \mathrm{~b}$ & $0.6 \pm 0.4$ & 6 & $\mathrm{P}$ & $174 \mathrm{a}-\mathrm{c}$ & $0.1 \pm 0.1 \mathrm{~cd}$ & 6 & $\mathrm{P}$ \\
\hline Canola (winter rape) & Amanda & $6,635 a b$ & $2.5 \pm 0.1$ & 2 & M & $436 \mathrm{ab}$ & $0.3 \pm 0.1 \mathrm{~cd}$ & 5 & $\mathrm{P}$ \\
\hline Canola (winter rape) & Dwarf Essex & $69 a b$ & $0.6 \pm 0.6$ & 3 & $\mathrm{P}$ & 79 a-c & $0.1 \pm 0.1 \mathrm{~cd}$ & 4 & $\mathrm{P}$ \\
\hline Canola (winter rape) & Salut & $7,964 a b$ & 2.9 & 1 & $\mathrm{M}$ & $8 \mathrm{bc}$ & $0.0 \pm 0.0 \mathrm{~d}$ & 2 & $\mathrm{~N}$ \\
\hline Canola (spring rape) & Hyola 401 & $\ldots$ & $\ldots$ & 0 & $\ldots$ & $67 \mathrm{a}-\mathrm{c}$ & $0.0 \mathrm{~d}$ & 1 & $\mathrm{~N}$ \\
\hline Canola (spring rape) & Goldrush & $62 \mathrm{ab}$ & 0.0 & 1 & $\mathrm{~N}$ & $464 a b$ & $0.2 \pm 0.1 \mathrm{~cd}$ & 4 & $\mathrm{P}$ \\
\hline Yellow mustard & IdaGold & $15,045 \mathrm{a}$ & $14.7 \pm 11.1$ & 5 & VG & $48 \mathrm{a}-\mathrm{c}$ & $0.4 \pm 0.4 \mathrm{~b}-\mathrm{d}$ & 2 & $\mathrm{P}$ \\
\hline Brown mustard & Pacific Gold & & & 0 & - & $221 \mathrm{a}-\mathrm{c}$ & $0.1 \pm 0.1 \mathrm{~cd}$ & 5 & $\mathrm{P}$ \\
\hline Camelina & Yellowstone & $3,596 \mathrm{ab}$ & $1.4 \pm 0.5$ & 2 & M & $719 a b$ & $0.3 \pm 0.1 \mathrm{~cd}$ & 2 & $\mathrm{P}$ \\
\hline Camelina & Blaine Creek & $68 \mathrm{ab}$ & 0.0 & 1 & $\mathrm{~N}$ & $476 \mathrm{ab}$ & $0.3 \pm 0.1 \mathrm{~cd}$ & 4 & $\mathrm{P}$ \\
\hline Camelina & Calena & $1,423 a b$ & 0.5 & 1 & $\mathrm{P}$ & $866 \mathrm{ab}$ & $0.3 \mathrm{~b}-\mathrm{d}$ & 1 & $\mathrm{P}$ \\
\hline Chickpea & Sierra & & & 0 & $\ldots$ & $3,161 \mathrm{a}$ & $1.1 \mathrm{a}-\mathrm{c}$ & 1 & M \\
\hline Chickpea & Myles & $144 a b$ & $1.0 \pm 1.0$ & 3 & $\mathrm{M}$ & $4 \mathrm{c}$ & $0.0 \pm 0.0 \mathrm{~d}$ & 3 & $\mathrm{~N}$ \\
\hline Chickpea & Dwelley & $4,760 a b$ & $1.9 \pm 0.7$ & 2 & $\mathrm{M}$ & $2,149 \mathrm{a}$ & $0.7 \mathrm{a}-\mathrm{d}$ & 1 & $\mathrm{P}$ \\
\hline Green field pea & Journey & $1,253 a b$ & $0.6 \pm 0.4$ & 2 & $\mathrm{P}$ & $2,093 \mathrm{a}$ & $0.7 \pm 0.0 \mathrm{~b}-\mathrm{d}$ & 2 & $\mathrm{P}$ \\
\hline Yellow field pea & Universal & $4,639 a b$ & $2.1 \pm 1.2$ & 2 & $\mathrm{M}$ & $1,961 \mathrm{a}$ & $0.8 \pm 0.3 \mathrm{a}-\mathrm{c}$ & 4 & $\mathrm{P}$ \\
\hline Yellow field pea & Badminton & $5,786 a b$ & $2.7 \pm 1.1$ & 4 & $\mathrm{M}$ & $1,175 \mathrm{a}$ & $0.7 \pm 0.5 \mathrm{~b}-\mathrm{d}$ & 2 & $\mathrm{P}$ \\
\hline Austrian winter field pea & Granger & $326 a b$ & $2.5 \pm 2.2$ & 3 & $\mathrm{M}$ & $3,932 \mathrm{a}$ & $1.4 \mathrm{ab}$ & 1 & M \\
\hline Winter lentil & Morton & $67 \mathrm{ab}$ & $0.8 \pm 1.4$ & 2 & $\mathrm{P}$ & $372 a-c$ & $0.1 \mathrm{~cd}$ & 1 & M \\
\hline Lentil & Athena & $3,264 a b$ & 1.2 & 1 & M & $8 \mathrm{bc}$ & $0.0 \pm 0.0 \mathrm{~d}$ & 2 & $\mathrm{~N}$ \\
\hline Lentil & Skyline & $51 \mathrm{ab}$ & 0.0 & 1 & $\mathrm{~N}$ & $\ldots$ & $\ldots$ & 0 & $\ldots$ \\
\hline Winter safflower & KN 144 & $296 a b$ & $0.6 \pm 0.3$ & 4 & $\mathrm{P}$ & $65 \mathrm{a}-\mathrm{c}$ & $0.1 \pm 0.0 \mathrm{~cd}$ & 4 & $\mathrm{P}$ \\
\hline Spring safflower & Gila & $2,093 \mathrm{ab}$ & $0.8 \pm 0.1$ & 4 & $\mathrm{P}$ & $50 \mathrm{a}-\mathrm{c}$ & $0.1 \pm 0.1 \mathrm{~cd}$ & 3 & $\mathrm{P}$ \\
\hline Spring safflower & Girard & $1,125 a b$ & $0.8 \pm 0.5$ & 3 & $\mathrm{P}$ & $117 \mathrm{a}-\mathrm{c}$ & $0.1 \pm 0.0 \mathrm{~cd}$ & 4 & $\mathrm{P}$ \\
\hline Sunflower & 2PD08 & $943 \mathrm{ab}$ & $0.4 \pm 0.1$ & 5 & $\mathrm{P}$ & $312 a-c$ & $0.1 \pm 0.0 \mathrm{~cd}$ & 6 & $\mathrm{P}$ \\
\hline Flax & Pembina & $1,026 \mathrm{ab}$ & $0.7 \pm 0.6$ & 2 & $\mathrm{P}$ & $244 \mathrm{a}-\mathrm{c}$ & $0.1 \pm 0.0 \mathrm{~cd}$ & 2 & $\mathrm{P}$ \\
\hline$P>F$ & & 0.0505 & 0.6704 & & & 0.0005 & 0.0002 & & \\
\hline $\mathrm{CV}(\%)$ & & 38.5 & 280.6 & & & 35.2 & 115.4 & & \\
\hline
\end{tabular}

${ }^{w}$ Final density of nematodes (nematodes/kg of soil plus roots) expressed as back-transformed means (BTM) from logarithmic transformations used to normalize data for ANOVA. Within a column, means followed by the same letter for each of the comparisons in eight assays did not differ significantly at $P$ $<0.05$ according to ANOVA using Least Significant Difference to separate means. Assays were over a 16-week incubation period.

${ }^{\mathrm{x}}$ Reproductive factor $(R f)$ and standard error of the mean (SE) calculated as the final nematode density ( $P f$, nematodes $/ \mathrm{kg}$ of soil) divided by the density of Pratylenchus initially added into soil (Pi, nematodes $/ \mathrm{kg}$ of soil); Pi rates were 2,014 P. neglectus $/ \mathrm{kg}$ of soil and 2,128 P. thornei/kg of soil.

${ }^{\mathrm{y}}$ Number of observations included in the analysis; $\mathrm{n}<8 / \mathrm{year}$ indicates a failure of seedling establishment.

${ }^{\mathrm{z}}$ Hosting ability ratings: $\mathrm{N}=$ nonhost $(R f<0.1), \mathrm{P}=$ poor host $(R f=0.1$ to 0.9$), \mathrm{M}=$ minor host $(R f=1.0$ to 4.9$), \mathrm{G}=\operatorname{good}$ host $(R f=5.0$ to 9.9$), \mathrm{VG}=$ very good host $(R f \geq 10.0)$. 
during our assays. These findings are important because canola production in the PNW is capable of expanding by up to one million acres in response to the impending startup of the region's first oilseed processing plant, which will become the largest oilseed processing plant in the United States. While cruciferous oilseed crops have been shown to reduce herbicide costs in wheat-oilseed rotations and to also sometimes increase wheat yields compared to wheat monocultures, these oilseed crops are also generically proclaimed by many advisory personnel, without evidence, to break the "disease cycle" of pathogens that invade wheat roots. This is clearly true for some but not all root-invading fungi, but it is not true for $P$. neglectus, the most widely distributed species of Pratylenchus in the rainfed, low-precipitation cropping systems of the PNW $(42,47)$. We have reported that some of the highest densities of $P$. neglectus encountered in our previous field trials have occurred in fields recently cropped with canola or yellow mustard $(37,39,40,44,46)$. For instance, a density of more than $11,000 P$. neglectus $/ \mathrm{kg}$ of soil was reported in an Oregon field after a crop of yellow mustard 'Tilney' (44). Major improvements in wheat yields were demonstrated by application of a nematicide in highly infested fields formerly cropped to canola or mustard, compared to a lack of response to nematicide in fields where densities of these Pratylenchus species were below detectable limits. Scientists in Australia, England, and Iran $(8,18,29,48,51,55)$ consider many or most canola cultivars to be moderate to good hosts of $P$. neglectus and $P$. thornei and capable of increasing the density of these species in soil when the crops are grown to maturity for oilseed, as also is the most common production practice in the PNW. Similar findings have shown the densities of $P$. penetrans become elevated before oilseed rape, including 'Dwarf Essex', is incorporated as a green manure crop in the PNW (11). As a contrast, our results showed that canola cultivars were not good hosts of $P$. thornei. Owen et al. (26) also found that densities of $P$. thornei were reduced during the production of canola crops. Unfortunately, they also reported a reduction of mycorrhizal fungi and subsequent reduction of wheat yield following canola, pointing out the need to consider the holistic effects of cropping systems rather than focusing on individual host-parasite interactions.

Brown mustard Pacific Gold was a good host of P. neglectus and a poor host of $P$. thornei. Daub et al. (6) reported that incorporation of another cultivar of brown mustard into soil as a green manure crop reduced the density of a mixture of $P$. neglectus and $P$. penetrans on a field in Germany. Mazzola et al. (20) reported that seed meals prepared from brown mustard suppressed densities of $P$. penetrans more than seed meals from canola or yellow mustard. In contrast, Bélair et al. (1) reported that the most susceptible host in their assay of $P$. penetrans multiplication on various crops was brown mustard, and that other good hosts included canola and yellow mustard. Bélair et al. (1) concluded that the "...most commonly recommended rotation crops [in Quebec] are suitable for the buildup of $P$. penetrans populations in the soil...". We demonstrated that canola Dwarf Essex was a very good host of P. neglectus. Hallbrendt et al. (15) previously reported that Dwarf Essex did not suppress Pratylenchus spp. density when this crop was incorporated into soil as a green manure. Potter et al. (29) found that susceptibility of canola roots to $P$. neglectus was dependent upon the presence in roots of a minimal threshold of 2-phenylethyl glucosinolate. Relationships between Pratylenchus spp. and cruciferous

Table 4. Multiplication rates and hosting abilities of Pratylenchus spp. for cultivars and species within dicotyledonous plant families during 2012

\begin{tabular}{|c|c|c|c|c|c|c|c|c|c|}
\hline \multirow[b]{2}{*}{ Common name } & \multirow[b]{2}{*}{ Cultivar } & \multicolumn{4}{|c|}{ P. neglectus } & \multicolumn{4}{|c|}{ P. thornei } \\
\hline & & BTM $^{w}$ & $R f \pm \mathrm{SE}^{\mathrm{x}}$ & $\mathbf{N}^{\mathrm{y}}$ & $\mathbf{H}^{\mathbf{z}}$ & BTM & $R f \pm \mathrm{SE}$ & $\mathbf{n}$ & $\mathbf{H}$ \\
\hline Unplanted soil, inoculated & & $716 \mathrm{~m}$ & $0.3 \pm 0.0 \mathrm{i}$ & 8 & $\ldots$ & $793 \mathrm{j}$ & $0.6 \pm 0.2 \mathrm{~h}$ & 8 & $\ldots$ \\
\hline Susceptible wheat & Louise & $16,008 \mathrm{bc}$ & $11.7 \pm 2.3 \mathrm{~b}-\mathrm{e}$ & 8 & VG & 39,426 a & $22.3 \pm 2.1 \mathrm{bc}$ & 8 & VG \\
\hline Susceptible wheat & Otis & $62,099 \mathrm{a}$ & $34.2 \pm 2.7 \mathrm{a}$ & 8 & VG & $48,059 \mathrm{a}$ & $26.4 \pm 2.4 \mathrm{~b}$ & 8 & VG \\
\hline Resistant wheat & AUS28451 & $12,855 \mathrm{~d}-\mathrm{h}$ & $5.9 \pm 0.7 \mathrm{e}-\mathrm{i}$ & 8 & $\mathrm{G}$ & $23,178 \mathrm{c}$ & $12.6 \pm 1.8 \mathrm{~d}-\mathrm{f}$ & 8 & VG \\
\hline Canola (winter rape) & Amanda & $70,728 \mathrm{a}$ & $31.8 \pm 3.2 \mathrm{a}$ & 8 & VG & $2,443 \mathrm{fg}$ & $1.4 \pm 0.3 \mathrm{~h}$ & 8 & M \\
\hline Canola (winter rape) & Dwarf Essex & $29,907 \mathrm{bc}$ & $15.5 \pm 3.2 \mathrm{bc}$ & 8 & VG & $1,621 \mathrm{~g}-\mathrm{i}$ & $0.9 \pm 0.1 \mathrm{~h}$ & 8 & $\mathrm{P}$ \\
\hline Canola (winter rape) & Salut & $23,562 \mathrm{~b}-\mathrm{d}$ & $12.4 \pm 2.8 b-\mathrm{e}$ & 8 & VG & $1,951 \mathrm{gh}$ & $1.0 \pm 0.1 \mathrm{~h}$ & 8 & M \\
\hline Canola (spring rape) & Hyola 401 & $31,277 \mathrm{a}-\mathrm{c}$ & $14.2 \pm 1.6 \mathrm{~b}-\mathrm{d}$ & 8 & VG & $1,860 \mathrm{~g}-\mathrm{i}$ & $1.0 \pm 0.1 \mathrm{~h}$ & 7 & $\mathrm{M}$ \\
\hline Canola (spring rape) & Goldrush & $25,890 \mathrm{~b}-\mathrm{d}$ & $18.2 \pm 5.5 \mathrm{~b}$ & 8 & VG & $1,293 \mathrm{~h}-\mathrm{j}$ & $0.9 \pm 0.2 \mathrm{~h}$ & 8 & $\mathrm{P}$ \\
\hline Yellow mustard & IdaGold & $18,197 \mathrm{~b}-\mathrm{e}$ & $11.6 \pm 3.8 \mathrm{~b}-\mathrm{f}$ & 8 & VG & $1,991 \mathrm{f}-\mathrm{h}$ & $1.1 \pm 0.2 \mathrm{~h}$ & 8 & M \\
\hline Brown mustard & Pacific Gold & 8,114 e-j & $5.7 \pm 2.1 \mathrm{e}-\mathrm{i}$ & 8 & $\mathrm{G}$ & $1,408 \mathrm{~g}-\mathrm{j}$ & $0.8 \pm 0.1 \mathrm{~h}$ & 8 & $\mathrm{P}$ \\
\hline Camelina & Yellowstone & $24,290 \mathrm{~b}-\mathrm{d}$ & $12.9 \pm 3.6 \mathrm{~b}-\mathrm{e}$ & 8 & VG & $1,215 \mathrm{~h}-\mathrm{j}$ & $0.8 \pm 0.2 \mathrm{~h}$ & 8 & $\mathrm{P}$ \\
\hline Camelina & Blaine Creek & 21,898 b-d & $10.3 \pm 1.6 \mathrm{c}-\mathrm{g}$ & 7 & VG & $1,434 \mathrm{~g}-\mathrm{i}$ & $0.9 \pm 0.2 \mathrm{~h}$ & 8 & $\mathrm{P}$ \\
\hline Camelina & Calena & $14,157 \mathrm{c}-\mathrm{g}$ & $8.6 \pm 2.8 \mathrm{c}-\mathrm{h}$ & 7 & $\mathrm{G}$ & $1,876 \mathrm{~g}-\mathrm{i}$ & $1.0 \pm 0.1 \mathrm{~h}$ & 8 & M \\
\hline Chickpea & Sierra & $16,871 \mathrm{~b}-\mathrm{f}$ & $8.5 \pm 1.8 \mathrm{c}-\mathrm{h}$ & 8 & G & $2,494 \mathrm{fg}$ & $1.5 \pm 0.4 \mathrm{~h}$ & 6 & M \\
\hline Chickpea & Myles & $16,741 \mathrm{~b}-\mathrm{f}$ & $7.6 \pm 0.9 \mathrm{~d}-\mathrm{i}$ & 8 & G & $22,838 \mathrm{c}$ & $12.6 \pm 2.3 \mathrm{~d}-\mathrm{f}$ & 8 & VG \\
\hline Chickpea & Dwelley & $7,848 \mathrm{f}-\mathrm{j}$ & $4.2 \pm 1.1 \mathrm{f}-\mathrm{i}$ & 8 & M & $3,583 \mathrm{f}$ & $2.0 \pm 0.3 \mathrm{~h}$ & 8 & M \\
\hline Green field pea & Journey & $5,653 \mathrm{~h}-\mathrm{j}$ & $3.2 \pm 0.8 \mathrm{~g}-\mathrm{i}$ & 7 & $\mathrm{M}$ & $76,041 \mathrm{a}$ & $47.5 \pm 9.2 \mathrm{a}$ & 8 & VG \\
\hline Yellow field pea & Universal & $1,452 \mathrm{~lm}$ & $0.9 \pm 0.3 \mathrm{i}$ & 8 & $\mathrm{P}$ & $9,678 \mathrm{e}$ & $5.5 \pm 1.0 \mathrm{gh}$ & 8 & $\mathrm{G}$ \\
\hline Yellow field pea & Badminton & $970 \mathrm{~m}$ & $0.7 \pm 0.3 \mathrm{i}$ & 8 & $\mathrm{P}$ & $8,101 \mathrm{e}$ & $4.7 \pm 1.0 \mathrm{~h}$ & 8 & M \\
\hline Austrian winter field pea & Granger & $5,092 \mathrm{i}-\mathrm{k}$ & $3.4 \pm 1.1 \mathrm{~g}-\mathrm{i}$ & 8 & $\mathrm{M}$ & $31,598 \mathrm{bc}$ & $17.6 \pm 3.2 \mathrm{c}-\mathrm{e}$ & 8 & VG \\
\hline Winter lentil & Morton & 8,475 e-i & $6.6 \pm 2.5 \mathrm{e}-\mathrm{i}$ & 8 & G & $12,307 \mathrm{de}$ & $6.5 \pm 0.7 \mathrm{f}-\mathrm{h}$ & 8 & $\mathrm{G}$ \\
\hline Lentil & Athena & $13,078 \mathrm{~d}-\mathrm{h}$ & $6.9 \pm 1.6 \mathrm{~d}-\mathrm{i}$ & 8 & G & $21,883 \mathrm{~cd}$ & $11.9 \pm 1.7 \mathrm{e}-\mathrm{g}$ & 8 & VG \\
\hline Lentil & Skyline & $6,463 \mathrm{~g}-\mathrm{j}$ & $4.0 \pm 1.2 \mathrm{~g}-\mathrm{i}$ & 8 & M & $30,986 \mathrm{bc}$ & $18.8 \pm 3.4 \mathrm{~cd}$ & 8 & VG \\
\hline Winter safflower & KN 144 & $2,407 \mathrm{kl}$ & $1.2 \pm 0.3 \mathrm{hi}$ & 8 & $\mathrm{M}$ & $1,893 \mathrm{~g}-\mathrm{i}$ & $1.0 \pm 0.1 \mathrm{~h}$ & 8 & M \\
\hline Spring safflower & Gila & 4,781 i-k & $3.8 \pm 1.5 \mathrm{~g}-\mathrm{i}$ & 8 & $\mathrm{M}$ & $1,059 \mathrm{ij}$ & $0.6 \pm 0.1 \mathrm{~h}$ & 8 & $\mathrm{P}$ \\
\hline Spring safflower & Girard & $4,309 \mathrm{i}-\mathrm{k}$ & $2.1 \pm 0.4 \mathrm{hi}$ & 8 & $\mathrm{M}$ & $1,646 \mathrm{~g}-\mathrm{i}$ & $0.9 \pm 0.1 \mathrm{~h}$ & 8 & $\mathrm{P}$ \\
\hline Sunflower & 2PD08 & $3,647 \mathrm{jk}$ & $1.8 \pm 0.3 \mathrm{hi}$ & 8 & $\mathrm{M}$ & $1,926 \mathrm{gh}$ & $1.0 \pm 0.1 \mathrm{~h}$ & 8 & $\mathrm{M}$ \\
\hline Flax & Pembina & $900 \mathrm{~m}$ & $0.8 \pm 0.5 \mathrm{i}$ & 8 & $\mathrm{P}$ & $1,336 \mathrm{~g}-\mathrm{j}$ & $0.7 \pm 0.1 \mathrm{~h}$ & 8 & $\mathrm{P}$ \\
\hline$P>F$ & & $<0.0001$ & $<0.0001$ & & & $<0.0001$ & $<0.0001$ & & \\
\hline CV (\%) & & 9.2 & 86.3 & & & 7.1 & 96.6 & & \\
\hline
\end{tabular}

${ }^{\text {w}}$ Final density of nematodes (nematodes/kg of soil plus roots) expressed as back-transformed means (BTM) from logarithmic transformations used to normalize data for ANOVA. Within a column, means followed by the same letter for each of the comparisons in eight assays did not differ significantly at $P$ $<0.05$ according to ANOVA using Least Significant Difference to separate means. Assays were over a 12-week incubation period.

${ }^{\mathrm{x}}$ Reproductive factor $(R f)$ and standard error of the mean (SE) calculated as the final nematode density ( $P f$, nematodes $/ \mathrm{kg}$ of soil) divided by the density of Pratylenchus initially added into soil (Pi, nematodes $/ \mathrm{kg}$ of soil); Pi rates were 2,317 P. neglectus $/ \mathrm{kg}$ of soil and 2,017 P. thornei/kg of soil.

${ }^{\mathrm{y}}$ Number of observations included in the analysis; $\mathrm{n}<8 / \mathrm{year}$ indicates a failure of seedling establishment.

${ }^{\mathrm{z}}$ Hosting ability ratings: $\mathrm{N}=$ nonhost $(R f<0.1), \mathrm{P}=$ poor host $(R f=0.1$ to 0.9$), \mathrm{M}=$ minor host $(R f=1.0$ to 4.9$), \mathrm{G}=\operatorname{good}$ host $(R f=5.0$ to 9.9$), \mathrm{VG}=$ very good host $(R f \geq 10.0)$. 
oilseed crops are clearly complex, depending upon whether the crop is grown to maturity or incorporated as a green manure, the identity and molar quantities of various glucosinolate compounds in roots, leaves, or seed of these crops, the degree to which foliar tissues are macerated when incorporated as a green manure, the water content of soil, and other factors $(2,28,29)$.

Chickpea is a well-known host of both $P$. thornei and P. neglectus $(3,5,12,26,48,51,54)$. Previous reports have included cultivars with low to moderate levels of resistance but not a high level of resistance to these Pratylenchus spp. Cultivars ranging from moderately resistant to moderately susceptible to $P$. thornei were reported by Owen et al. (26). Cultivars of interest in the PNW also varied in hosting ability for these species. Chickpea Myles was a good host for both species, but Sierra was a good host only to $P$. neglectus; Dwelley was a minor host of both species. Further screening of additional cultivars appears to be necessary to more fully define potential effects of Pratylenchus spp. on rotations of wheat and food legume crops in the PNW.

Reports of pea and lentil cultivars as hosts or nonhosts of $P$. neglectus and $P$. thornei have been varied. Pea and lentil were hosts of $P$. thornei in Syria (12), and pea was a minor host of $P$. thornei in Israel (25). Pea and lentil are hosts of both P. neglectus and $P$. thornei in the PNW (31), but nearly all of the numerous pea and lentil cultivars tested in Australia were resistant to each of these Pratylenchus spp. $(18,48,54)$. We found field pea 'Journey' and 'Granger' to be very good hosts of $P$. thornei and minor hosts of $P$. neglectus. Journey supported the highest multiplication rate encountered for $P$. thornei during the course of these experiments. Yellow pea Badminton was a poor to minor host of both nematode species, whereas yellow pea Universal was a good host of $P$. thor$n e i$ and a poor host of $P$. neglectus. Lentil Athena and Morton were good to very good hosts of both nematode species, whereas lentil Skyline was a very good host of $P$. thornei and a minor host of $P$. neglectus. It would be of interest to screen selected cultivars of pea and lentil against $P$. neglectus and $P$. thornei isolates from the PNW and from Australia to determine if differences in susceptibility occur among prevalent cultivars in each country or if the discrepancies in ratings of hosting abilities are due to genetic diversity within the Pratylenchus spp. in each country. Screening of additional pea and lentil cultivars will be important to provide more specific guidance in developing more efficient rotational cropping systems for producers in the PNW.

Each of the cultivars of safflower, sunflower, and flax in our assays was classified as a poor or minor host of both species of Pratylenchus. Safflower was classified as resistant to both Pratylenchus spp. in southern Australia (54), and flax was considered resistant to both Pratylenchus spp. in northeast Australia (51). In southern Australia, flax was also reported as resistant to P. thornei, and no information regarding the reaction of flax to $P$. neglectus was reported $(18,54)$. Sunflower was reported as resistant to $P$. neglectus and moderately susceptible to $P$. thornei in southern Australia (54). The latter report suggests the possibility of different hosting abilities among sunflower cultivars, which was not able to be examined during our assays. However, most evidence suggests that these oilseed crops are not good hosts for these two species of Pratylenchus, as was also found in our study.

Wheat cultivars used as controls in these assays confirmed previous reports that Louise and Otis are more efficient hosts than AUS28451 for multiplication of $P$. neglectus and P. thornei (33$35,39,49)$. Multiplication rates of both nematode species were greater on susceptible wheat controls during 2012 compared to 2011, when the incubation conditions appeared less favorable to both the nematodes and the plants. The reasons for the differences between years are unknown but may relate to differential effects of abiotic conditions. While the same soil was used for all of our assays, it is possible that differences could have occurred for soil moisture, soil temperature, or virulence of the inoculum. Our assay soils were watered by capillarity from the bottom during 2011 and were hand watered from the top during 2012. While the subirrigation system has been effective in our previous assays of wheat
$(33,36,49)$, we made this change in an attempt to improve multiplication rates by assuring that the complete soil column could not become saturated with water during 2012. Also, it is possible that temperatures could have varied slightly during different years. Effects of moisture and other edaphic conditions on survival and on invasion of roots by various Pratylenchus spp. were reviewed by Castillo and Vovlas (4). Inoculum virulence could also have differed in response to differences in inoculum rearing conditions (carrot cultivar, culture age, proportions of different nematode life stages) and to storage of inoculum suspensions (temperature or time) before dispersal into soil during the 2 years of this experiment. Every effort was made to assure uniformity over years and we are not aware of any differences in our inoculum rearing and handling procedures; this appears to us to be a less likely explanation than the manner in which pots were watered during the 2 years. Nevertheless, Townshend (52) reported that survival of $P$. neglectus in soil was greater for adults and fourth-stage juveniles than for second- and third-stage juveniles, and we did not attempt to quantify life stages of the nematodes applied to our soils.

Results of these assays provide insights that should be included among considerations for improving the efficiency of rainfed production systems in the PNW. It is likely that reduced efficiency of wheat production is associated with rotations that include multiple crops that are each good hosts of Pratylenchus spp., such as now appears to be very likely for some wheat-food legume or wheatbrassica rotations.

\section{Acknowledgments}

This research was funded by a grant from the USDA Cooperative State Research, Extension and Education Service Solutions to Economic and Environmental Problems (STEEP) Pacific Northwest Regional Research Program. Supplemental funding was from the Oregon Agricultural Experiment Station and a United States Department of Agriculture Agricultural Research Service (USDAARS) subcontract to Oregon State University (OSU; SCA number 58-5348-9100). Seed was provided by Jeron Chatelain and Stephen Machado, Steve Petrie, and Don Wysocki (OSU, Pendleton), Duane Johnson (Phoenix Rising, Inc., Bigfork, MT), and Harold Collins (USDA-ARS, Prosser, WA). We also appreciated technical assistance by Mike Baxter, Cameron Dumont, Alysha Hitzman, Stephen Isbell, Paul Thorgersen, and Nick Webster.

\section{Literature Cited}

1. Bélair, G., Fournier, Y., Dauphinais, N., and Dangi, O. P. 2002. Reproduction of Pratylenchus penetrans on various rotation crops in Quebec. Phytoprotection 83:111-114.

2. Brown, P. D., and Morra, M. J. 1997. Control of soil-borne plant pests using glucosinolate-containing plants. Adv. Agron. 61:167-231.

3. Castillo, P., Jimenez-Diaz, R. M., Gomez-Barcina, A., and Vovlas, N. 1995. Parasitism of the root-lesion nematode Pratylenchus thornei on chickpea. Plant Pathol. 44:728-733.

4. Castillo, P., and Vovlas, N. 2007. Pratylenchus, Nematoda, Pratylenchidae: Diagnosis, biology, pathogenicity and management. Nematol. Monogr. Perspect. 6:1-530.

5. Castillo, P., Vovlas, N., and Jimenez-Diaz, R. M. 1998. Pathogenicity and histopathology of Pratylenchus thornei populations on selected chickpea genotypes. Plant Pathol. 47:370-376.

6. Daub, M., Schlathölter, M., Schütze, W., Grosch, R., and Hallmann, J. 2008. Effect of biofumigation on population dynamics of Pratylenchus spp. Proc. 5th Int. Congr. Nematol., Brisbane, Australia. p. 278.

7. Dickerson, O. J., Frantz, J. J., and Lash, L. D. 1978. Influence of crop rotation on nematode populations in Kansas. J. Nematol. 10:284.

8. Fatemy, S., Abootorabi, E., Ebrahimi, N., and Aghabeigi, F. 2006. First report of Pratylenchus neglectus and P. thornei infecting canola and weeds in Iran. Plant Dis. 90:1555.

9. Fenwick, G. R., Heany, R. K., and Mullin, W. J. 1994. Glucosinolates and their breakdown products in food and food plants. CRC Crit. Rev. Food Sci. Nutr. 18:123-201.

10. Ferris, H. L., Carlson, D. R., Viglierchio, D. R., Westerdahl, B. B., Wu, F. W., Anderson, C. E., Juurma, A., and Kirby, D. W. 1993. Host status of selected crops to Meloidogyne chitwoodi. J. Nematol. 25(4S):849-857.

11. Forge, T. A., Ingham, R. E., Kaufman, D., and Pinkerton, J. N. 2000. Population growth of Pratylenchus penetrans on winter cover crops grown in the Pacific Northwest. J. Nematol. 32:42-51.

12. Greco, N., Di Vito, M., Saxena, M. C., and Reddy, M. V. 1988. Investigation on the root lesion nematode Pratylenchus thornei, in Syria. Nematol. Mediterr. 16:101-105.

13. Hafez, S. I., Golden, A. M., Rashid, R., and Handoo, Z. 1992. Plant-parasitic nematodes associated with crops in Idaho and eastern Oregon. Nematropica 22:193-204. 
14. Hajihassani, A., Smiley, R. W., and Afshar, F. J. 2013. Effects of co-inoculations with Pratylenchus thornei and Fusarium culmorum on growth and yield of winter wheat. Plant Dis. 97:1470-1477.

15. Hallbrendt, J. M., LaMondia, J. A., and Zasada, I. A. 2008. Evaluation of millet and rapeseed as rotation or green manure crops to control nematodes in orchard replant sites. Proc. 5th Int. Congr. Nematol., Brisbane, Australia. p. 280.

16. Handoo, Z. A., and Golden, A. M. 1989. A key and diagnostic compendium to the species of the genus Pratylenchus Filipjev, 1936 (lesion nematodes). J. Nematol. 21:202-218.

17. Hollaway, G. J. 2002. Effect of oat (Avena sativa) on the population density of Pratylenchus thornei in the field. Australas. Plant Pathol. 31:147-149.

18. Hollaway, G. J., Taylor, S. P., Eastwood, R. F., and Hunt, C. H. 2000. Effect of field crops on density of Pratylenchus in southeastern Australia: P. thornei. J. Nematol. 32(4S):600-608.

19. MacGuidwin, A. E., and Layne, T. L. 1995. Response of nematode communities to sudangrass and sorghum-sudangrass hybrids grown as green manure crops. J. Nematol. 27(4S):609-616.

20. Mazzola, M., Brown, J., Zhao, X., Izzo, A. D., and Fazio, G. 2009. Interaction of brassicaceous seed meal and apple rootstock on recovery of Pythium spp. and Pratylenchus penetrans from roots grown in replant soils. Plant Dis. 93:51-57.

21. Mojtahedi, H., Santo, G. S., and Ingham, R. E. 1993. Suppression of Meloidogyne chitwoodi populations with selected sudangrass and sorghumsudangrass cultivars as green manure. J. Nematol. 25:303-311.

22. Moody, E. H., Lownsbery, B. F., and Ahmed, J. M. 1973. Culture of the root-lesion nematode Pratylenchus vulnus on carrot disks. J. Nematol. 19:125-134.

23. O'Brien, P. C. 1982. A study of the host range of Pratylenchus thornei. Australas. Plant Pathol. 11:3-5.

24. Oostenbrink, M. 1966. Major characteristics of the relation between nematodes and plants. Meded. Landbo. Wageningen 66:3-46.

25. Orion, D., Krikun, J., and Sullami, M. 1979. The distribution, pathogenicity and ecology of Pratylenchus thornei in the northern Negev. Phytoparasitica 7:3-9.

26. Owen, K. J., Clewett, T. G., and Thompson, J. P. 2012. What is the impact of winter grain crops on Pratylenchus thornei grown in rotation with tolerant and intolerant wheat? Proc. 7th Australas. Soilborne Dis. Sympos., Fremantle, WA. p. 67

27. Owen, K. J., Thompson, J. P., and Clewett, T. G. 2010. Pre-cropping with canola decreased Pratylenchus thornei populations, arbuscular mycorrhizal fungi, and yield of wheat. Crop Pasture Sci. 61:399-410.

28. Potter, M. J., Davies, K., and Rathjen, A. J. 1998. Suppressive impact of glucosinolates in Brassica vegetative tissues on root lesion nematode Pratylenchus neglectus. J. Chem. Ecol. 24:67-80.

29. Potter, M. J., Vanstone, V. A., Davies, K. A., Kirkegaard, J. A., and Rathjen, A. J. 1999. Reduced susceptibility of Brassica napus to Pratylenchus neglectus in plants with elevated root levels of 2-phenylethyl glucosinolate. J. Nematol. 31:291-298.

30. Proctor, J. R., and Marks, C. F. 1974. The determination of normalising transformations for nematode count data from soil samples and of efficient sampling schemes. Nematologica 20:395-406.

31. Riga, E., Porter, L. D., Mojtahedi, H., and Erickson, D. 2008. Pratylenchus neglectus, $P$. thornei, and Paratylenchus hamatus nematodes causing yield reduction to dryland peas and lentils in Idaho. Plant Dis. 92:979.

32. Schillinger, W. F., Papendick, R. I., Guy. S. O., Rasmussen, P. E., and Van Kessel, C. 2006. Dryland cropping in the western United States. Pages 365-393 in: Dryland Agriculture, 2nd ed. G. A. Peterson, P. W. Unger, and W. A. Payne, eds. Agron. Monogr. 23, American Society of Agronomy, Madison, WI.

33. Sheedy, J. G., Raupp, W. J., Thompson, A. L., and Smiley, R. W. 2008. Resistance to root lesion nematodes of Chinese Spring $\times$ Aegilops speltoides addition lines; Pratylenchus neglectus and P. thornei. Plant Dis. Manag. Rep. 2:N038.

34. Sheedy, J. G., Smiley, R. W., Easley, S. A., and Thompson, A. L. 2007. Resistance reaction of Pacific Northwest spring wheat and barley cultivars to root-lesion nematode; Pratylenchus neglectus. Plant Dis. Manag. Rep. 1:CF022.

35. Sheedy, J. G., Smiley, R. W., Easley, S. A., and Thompson, A. L. 2008. Root-lesion nematode resistance reaction of Pacific Northwest spring wheat and barley cultivars; Pratylenchus thornei. Plant Dis. Manag. Rep. 2:N007.

36. Sheedy, J. G., Smiley, R. W., Hayes, P. M., Thompson, A. L., Easley, S. A. and Corey, A. E. 2008. Resistance to root lesion nematode of barley entries in the Coordinated Agricultural Project; Pratylenchus thornei. Plant Dis. Manag. Rep. 2:N037.

37. Smiley, R. W. 2010. Root-lesion nematodes reduce yield of intolerant wheat and barley. Agron. J. 101:1322-1335.

38. Smiley, R. W. 2010. Root-lesion nematodes: Biology and management in Pacific Northwest wheat cropping systems. PNW Ext. Bull. 617, Oregon State University, Corvallis.

39. Smiley, R. W., Gourlie, J. A., Yan, G. P., and Rhinhart, K. E. L. 2014. Resistance and tolerance of landrace wheat in fields infested with Pratylenchus neglectus and P. thornei. Plant Dis. 98:797-805.

40. Smiley, R. W., and Machado, S. 2009. Pratylenchus neglectus reduces yield of winter wheat in dryland cropping systems. Plant Dis. 93:263-271.

41. Smiley, R. W., Machado, S., Gourlie, J. A., Pritchett, L. C., Yan, G. P., and Jacobsen, E. E. 2013. Effects of crop rotation and tillage on Pratylenchus species in the semi-arid Pacific Northwest USA. Plant Dis. 97:537-546.

42. Smiley, R. W., Merrifield, K., Patterson, L.-M., Whittaker, R. G., Gourlie, J A., and Easley, S. A. 2004. Nematodes in dryland field crops in the semiarid Pacific Northwest USA. J. Nematol. 36:54-68.

43. Smiley, R. W., and Nicol, J. M. 2009. Nematodes which challenge global wheat production. Pages 171-187 in: Wheat Science and Trade. B. F. Carver, ed. Wiley-Blackwell, Ames, IA.

44. Smiley, R. W., Sheedy, J. G., and Easley, S. A. 2008. Vertical distribution of Pratylenchus spp. in silt loam soil of Pacific Northwest dryland crops. Plant Dis. 92:1662-1668

45. Smiley, R. W., Whittaker, R. G., Gourlie, J. A., and Easley, S. A. 2005 Pratylenchus thornei associated with reduced wheat yield in Oregon. J. Nematol. 37:45-54.

46. Smiley, R. W., Whittaker, R. G., Gourlie, J. A., and Easley, S. A. 2005 Suppression of wheat growth and yield by Pratylenchus neglectus in the $\mathrm{Pa}$ cific Northwest. Plant Dis. 89:958-968.

47. Strausbaugh, C. A., Bradley, C. A., Koehn, A. C., and Forster, R. L. 2004 Survey of root diseases of wheat and barley in southeastern Idaho. Can. J. Plant Pathol. 26:167-176.

48. Taylor, S. P., Hollaway, G. J., and Hunt, C. H. 2000. Effect of field crops on population densities of Pratylenchus neglectus and P. thornei in southeastern Australia: P. neglectus. J. Nematol. 32:591-599.

49. Thompson, A. L., Sheedy, J. G., Campbell, K. G., Okubara, P. A., and Smiley, R. W. 2008. Resistance of wheat to the root lesion nematode; Pratylenchus thornei. Plant Dis. Manag. Rep. 2:N039.

50. Thompson, J. P., Mackenzie, J., and Amos, R. 1995. Root-lesion nematode (Pratylenchus thornei) limits response of wheat but not barley to stored soil moisture in the Hermitage long-term tillage experiment. Aust. J. Exp. Agric. 35:1049-1055.

51. Thompson, J. P., Owen, K. J., Stirling, G. R., and Bell, M. J. 2008. Rootlesion nematodes (Pratylenchus thornei and P. neglectus): A review of recent progress in managing a significant pest of grain crops in northern Australia. Australas. Plant Pathol. 37:235-242.

52. Townshend, J. L. 1973. Survival of Pratylenchus penetrans and P. minyus in two Ontario soils. Nematologica 19:35-42.

53. Townshend, J. L. 1989. Population densities of four species of root-lesion nematodes (Pratylenchus) in the oat cultivars, Saia and OAC Woodstock. Can. J. Plant Sci. 69:903-905

54. Vanstone, V. A., Hollaway, G. J., and Stirling, G. R. 2008. Managing nematode pests in the southern and western regions of the Australian cereal in dustry: Continuing progress in a challenging environment. Australas. Plant Pathol. 37:220-234.

55. Webb, R. M. 1996. In vitro studies of six species of Pratylenchus (Nematoda: Pratylenchidae) on four cultivars of oilseed rape (Brassica napus var. oleifera). Nematologica 42:89-95.

56. Whitehead, A. G., and Hemming, J. R. 1965. A comparison of some quantitative methods of extracting small vermiform nematodes from soil. Ann. Appl. Biol. 55:25-38.

57. Yan, G. P., Smiley, R. W., Okubara, P. A., Skantar, A., Easley, S. A., Sheedy, J. G., and Thompson, A. L. 2008. Detection and discrimination of Pratylenchus neglectus and $P$. thornei in DNA extracts from soil. Plant Dis. 92:1480-1487. 